\title{
Evaluation of antiviral activity of Manuka honey against SARS-CoV-2
}

\author{
Israa ElBashir ${ }^{1,3}$, Aisha Nasser J M Al-Saei ${ }^{3}$, Paul J Thornalley ${ }^{2}$ and Naila Rabbani ${ }^{3}$
}

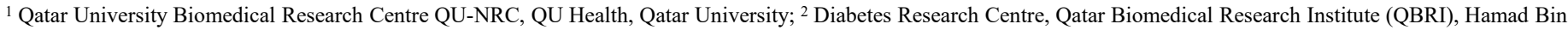
Khalifa University, Qatar Foundation; and ${ }^{3}$ College of Medicine, QU Health, Qatar University

\section{INTRODUCTION}

Severe acute respiratory syndrome coronavirus (SARSCoV-2) has been documented in Wuhan city in China during the end of the year 2019. On 11 March 2020 the World Health Organization (WHO) announced COVID 19 as a pandemic. COVID-19 has a variety of indications from asymptomatic infection to normal cold and flu or severe pneumonia or death. Hence, boosting of the immune system is crucial to ease the complication coupled with it. Natural immunity boosters, such as honey, have been utilized by humans for centuries. An in silico study showed the latent possibility of Manuka honey capability in inhibiting SARS-CoV-2 proteases (Hashem, 2020). Manuka honey contains high concentrations of methylglyoxal (MG) that can inhibit enveloped virus growth in vitro. MG is dicarbonyl compound that is endogenously formed under physiological conditions, contributing to modifying proteins and DNA that cause misfolding and deactivation. However, in a healthy human MG exogenously consumed has limited bioavailability (Degen et al., 2013), likely due to metabolism by intestinal bacteria. MG content in fresh Manuka honey ranges between $50-250 \mathrm{mg} / \mathrm{kg}$, while in commercial Manuka honey it varies between $70-700 \mathrm{mg} / \mathrm{kg}$ (Atrott et al., 2012). Degan et al. calculated the daily quantity of MG intake between $5-20 \mathrm{mg} / \mathrm{day}(0.1-0.3 \mathrm{mmol} / \mathrm{day})$ where Rabbani et al. (2016) estimated this value was lower, $<0.03 \mathrm{mmol} \mathrm{MG} / \mathrm{day}$. Endogenous formation of MG in healthy human adults subjects is $c a .3 \mathrm{mmol}$ per day (Rabbani et al. 2016). The MG content of Manuka honey is unlikely to be hazardous to health and be readily metabolized. Manuka honey may have antiviral activity against SARS-CoV-2 linked to its MG content. The study aims to characterize this by incubating SARSCoV-2 with Manuka honey in cell-free medium before exposing it to Vero cells and assessing viral infectivity and growth at multiplicity of infection (MOI) of 0.1.

\section{METHODOLOGY}

Day 1:

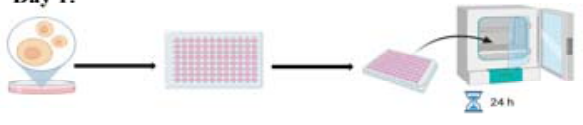

I. Cells culture: In a 96-well plate 15,000 vero cells were seeded and incubated for 24 hours.

Day 2:

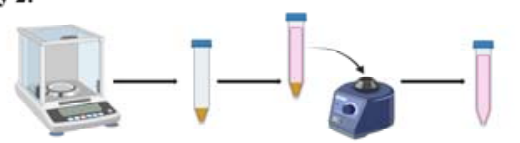

I. Preparation of honey solution:-Manuka honey $(250+$ MG) was diluted with basal medium 10 -folds to a final volume of $10 \mathrm{~mL}$ attaining a final concentration of $500 \mu \mathrm{M}$ MG.

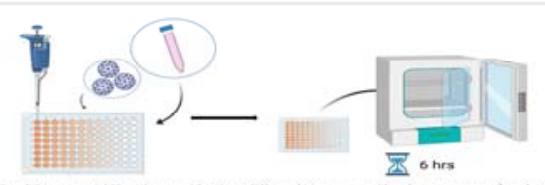

II. Honey dilution plate: The honey solution was further diluted to $250 \mu \mathrm{M}, 225 \mu \mathrm{M}, 200 \mu \mathrm{M}, 175 \mu \mathrm{M}, 150 \mu \mathrm{M}, 125$ $\mu \mathrm{M}$. The virus titre was $0.1 \mathrm{MOI}$ of SARS-CoV-2 virus. Controls used were : manuka honey $(500 \mu \mathrm{M})$ with aminoguanidine (1 mM), Manuka honey only and the vins aminoguanidime (1 mM), Manuka honey only and the virus Manuka ( 3 hours) with aminoguanidine -it is a potent scavenger of MG

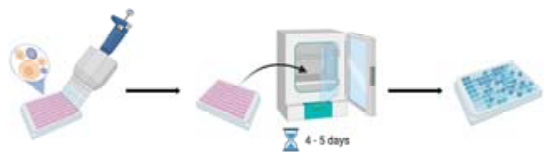

III. Viral infection: The cells were incubated with the virus until a significant CPE was seen. $\mathrm{TCID}_{\varepsilon_{0}}$ was then preformed to evaluate the virus inhibition.
RESULTS

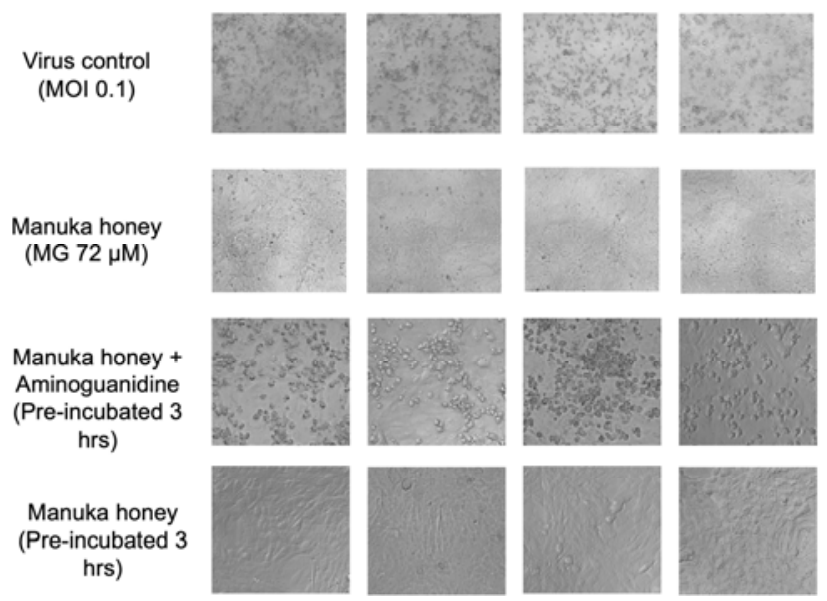

Figure 1: Effects of manuka honey on inhibiting SARS-CoV-2 at different MG concentrations with and without Aminoguanidine incubation. Vero cells treated with wild-type SARS-CoV-2 with titers of multiplicities of infection (MOI) 0.1 incubated with different dilutions of manuk a.

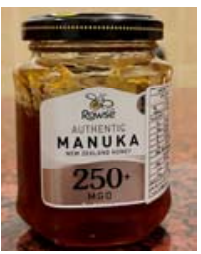

b.

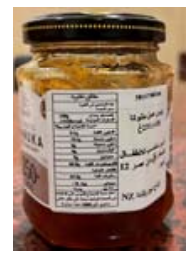

c.

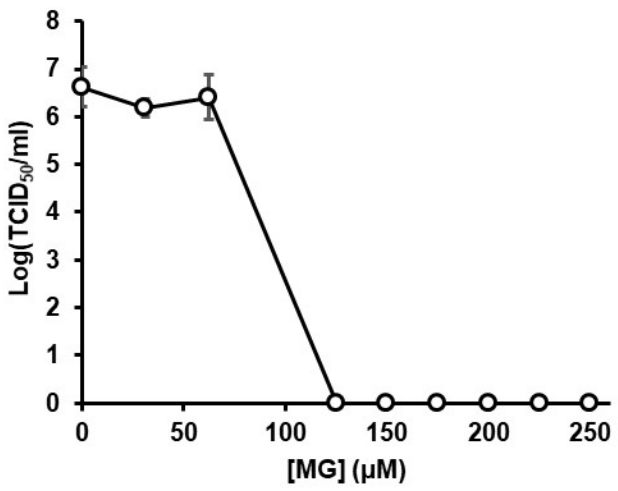

Figure 2: a. and b. Manuka honey used in the experiments c. Inhibition of SARS-CoV-2 by manuka honey dilutions. Diluted Manuka honey - shown at equivalent MG concentration - inhibited SARS-CoV-2 replication in Vero cells (MOI $=0.1$ ). SARS-CoV-2 was incubated in diluted Manuka honey in medium at $37^{\circ} \mathrm{C}$ for $3 \mathrm{~h}$ before adding to Vero cells. Cell supernatants were collected for virus titer $\left(\mathrm{TCID}_{50}\right)$ determination. Data are mean $\pm \mathrm{SD}, \mathrm{n}=4-8$ biological replicates. Data analysis was by logistic regression: $\ln \left(\mathrm{E} / \mathrm{E}_{\max }-\mathrm{E}\right)$ against $\ln ([\mathrm{MG}] / \mu \mathrm{M})$ where $\mathrm{E}$ is cytopathic effect. $\mathrm{TCID}_{50}$ (mean $\pm \mathrm{SD}$ ) was deduced by interpolation.

$\mathrm{EC}_{50}=72 \pm 2 \mu \mathrm{M} \mathrm{MG}$ equivalents.

\section{DISCUSSION}

Antiviral activity of Manuka honey against SARS-CoV-2 was detected for the first time in vitro. The virus titer was inhibited by $100 \%$ with MOI 0.1 when treated with $\geq 125$ $\mu \mathrm{M}$ MG equivalents of commercial $250+$ grade Manuka honey. The inhibition of the virus was microscopically viewed for the presence or absence of cytopathicity in quadruplicate wells. Virus titer $\left(\mathrm{TCID}_{50}\right)$ determination further confirmed the efficacy of inhibiting SARS-CoV-2 MOI 0.1 replicated in Vero cells (Figure 2). Prior incubation of diluted Manuka honey with the $\mathrm{MG}$ scavenger, aminoguanidine (AG), abolished the antiviral effect. This suggests that MG content of Manuka honey may be the active component producing the antiviral activity.

\section{CONCLUSION}

Manuka honey has antiviral activity against SARS-CoV2 when incubated with the virus in cell-free media at no greater than ca. 40-fold dilutions of $250+$ grade. Antiviral activity was inhibited by $\mathrm{AG}$, consistent with the anti-viral effect being mediated by MG. Manuka honey dilutions in MG equivalents had similar antiviral effect compared to authentic $\mathrm{MG}$, also consistent with $\mathrm{MG}$ content of Manuka honey mediating the antiviral effect. Whilst Manuka honey may inactivate SARS-CoV-2 in cell-free culture medium, its antiviral activity in vivo for other than topical application may be limited because of the rapid metabolism of MG by the glyoxalase system and limited bioavailability of oral MG.

\section{REFERENCES}

Atrott, J., Haberlau, S., \& Henle, T. (2012). Studies on the formation of methylglyoxal from dihydroxyacetone in manuka (leptospermum scoparium) honey. Carbohydrate Research, 361, 7- 11. https://doi.org/10.1016/j.carres.2012.07.025

Degen, J., Hellwig, M., \& Henle, T. (2012). 1,2-Dicarbonyl compounds in commonly $\quad$ consumed foods. Journal of Agricultural and Food Chemistry, 60(28), 7071-7079. https://doi.org/10.1021/jf301306g

Degen, J., Vogel, M., Richter, D., Hellwig, M., \& Henle, T. (2013). Metabolic transit of dietary

Methylglyoxal. Journal of Agricultural and Food Chemistry, 61(43), 10253-10260. https://doi.org/10.1021/jf304946p

Hashem, H. (2020). In silico approach of some selected honey constituents as sars-cov-2 main protease (covid-19) inhibitors. https://doi.org/10.26434/chemrxiv. 12115359 Rabbani, N., Xue, M. and Thornalley, P.J. (2016) Methylglyoxal-induced dicarbonyl stress in aging and disease: first steps towards glyoxalase 1-based treatments. Clin. Sci.
130, $1677-1696$

\section{ACKNOWLEDGMENTS}

We thank Qatar Foundation and Qatar University for funding for this research. This research was funded by QU grants: QUHI-CMED-21/22-1 